the frequency and the likelihood of ultimate success of an action aimed at surmounting statutory cost limitations.

Since its procedural advantages may be more than offset by its tendency to undercut the traditional protection afforded to bona fide litigants, other jurisdictions might hesitate to adopt the practice suggested by the New York Court.

\title{
"ACCIDENT" v. "INJURY" IN WORKMEN'S COMPENSATION: A DISTINCTION WITH A DIFFERENCE;
}

Workaren's Compensation Acts, by imposing absolute liability on employers, shift from injured workmen to industry the financial burden of disabilities "arising out of and in the course of employment." 1 Many of these acts require that claims be asserted within a period of limitations running from the date of the "injury," 2 thus permitting recovery even where no disability develops until long after the original mishap. ${ }^{3}$ But five states, apparently desiring to give employers greater protection against stale

* Whitted v. Palmer-Bee Co., 228 N.C. 417, 46 S.E.2d 109 (19.45).

1. Workmen's Compensation Acts are currently in force in all states exeept Mississippi. See, generally, SchneIDER, Workaren's Cosmens.tito:i Statutes (3rd ed. 1939);

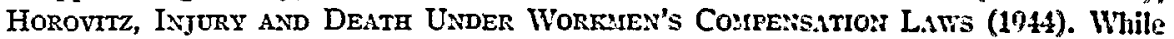
statutes differ in particulars, most of them are patterned after the early Bririsn Co:IrE: TION ACT of $1897,60 \& 61$ Vicr., c. 37 as changed by the Act of 1906, 6 Enw. 7, c. 58 . Sce 1 SChNeIDER, WorkareN's CoMipensation Text \$ 9 (3rd ed. 1941).

2. 44 Stat., 1432 (1927), 33 U.S.C. 913 (1946); ARIz. CodE, c. 56, art. 9, §56-967 (1939); ARK. Work. Courp. LAW $\$ 18$ (Pope, 1944 Supp.); C.IL. L.Idor CODE, Div. IV, c. 2, $\S 5405$ (Deering, 1943); Colo. Stat., c. 97, $\$ 363$ (1935); FL.1. ST.1T. Aws., tit. 29, $§ 410.19$ (1943); IowA CoDE, c. $85, \S \$ 5.26$ (1946); MID. CODE, art. 101, 51 (Flacls, 1939); Mrr::.. StaT., c. 23A, $\$ 4282$ (Mason, 1927); Mo. Rev. St.1T., c. 29, $\$ 3727$ (1947 Supp.); OHIO GE:. Code, c. 28b, § 1465-72a (Page, 1937); Orz.1. ST.1T., tit. \$5, §43 (1938); R.I. Gre.. L.1ws, c. 300, art. III, $\$ 17$ (1938); S.D. CODE, c. 64, tit. 64.0611 (1939); TENa. CODE, c. $42, \$ 68 \& 1$ (Williams, 1934); VT. StaT., c. 353, $\$ 3110$ (1947); Wasu. Rev. Srar., tit. 50, c. 7, $\$ 76 \$ 6$ (Remington, 1932); W. V.. CodE $\$ 2540$ (1943); Wrs. Sr.1r., c. 102, $\$ 102.12$ (1947).

In New Mexico, where the statute requires that claims be filcd vithin a year of the employer's refusal to pay compensation, N.M. ST.1T., c. 57, art. 9, $\$ 57-913$ (1943), judicial interpretation has made "injury" the operative event initiating the prescriptive pariod. Anderson v. Contract Trucking Co., 48 N.MI. 158, 146 P.2d 873 (1944).

3. E.g., Kropp v. Parker, S F. Supp. 290 (D. MId. 1934) (tumor developing fiften months after the original blow); Hartford A. \& I. Co. v. Industrial Commiszion, 23 Ariz. 50, 29 P.2d 142 (1931) (cancer appearing two years after the aceident); Acme Body Worls v. Koespel, 204 Wis. 493, 234 N.W. 756 (1931) (cataract developing six years after the aecident).

But the word "injury" may not be an automatic talisman: two states using the term deny recovery for latent injuries (see note 6 infra), while three states permit recovery despite apparently more restrictive phrasing (see note 7 infra). 
or fraudulent claims, ${ }^{4}$ have joined a sizable minority by discarding the "injury" limitation in favor of one running from the date of the "accident." : While a layman might find little difference between these two provisions, ${ }^{\circ}$ legal semantics can transmute it into a difference of recovery or non-recovery: where latent injuries do not appear until after the period from the date of the "accident" has run, an employee's right of action is extinguished before it ever matures.7

The limited coverage provided by an "accident" type statute was recently highlighted in the North Carolina case of Whitted v. Palmer-Bee Co. Plain-

4. See note $21 \mathrm{infra}$. Such protection seems to be the major purpose of a statute of limitation on compensation claims. See Steffens Ice Cream Co. v. Jarvis, 132 Okla. 300, 301, 270 Pac. 1103, 1104 (1928).

5. The statutes thus converted are: Conn. Public Acts 1927, c. 307, 5 and ILL. SraT., c. $48, \S 161$ (as amended July 24,1939 , Laws 1939 , p. $601, \S 1$, Smith-Hurd, 1939) (both changing limitation from one year after date of injury to one year after date of accident); IND. STaT., tit. 40, c. 12, $\$ 40-1224$ (Burns, 1947 Supp.) (two years from date of accident rather than two years from date of injury). LA. GeN. STat., $\S 4420$ (Act, 1914, No. 20, $\S 31$; as amended by Act No. 29, $\S 1$ of 1934, Dart, 1939) (now six months after accident where injury obvious, and two years where injury latent instead of one year from injury; sce p. 0000 infra). In Utah, where courts in workmen's compensation cases had previously applied a general one year statute running from the date of compensable disability, Salt Lake City v. Industrial Commission, 93 Utah 510, 74 P.2d 657 (1937), the Act was amended to require that all claims be filed within three years of the accident. Utah Code Annotated, 42-1-92, as amended by L. 39, c. 51 (1943).

In addition, the minority of twenty-one states includes: ALA. CODE, tit. 26, $\$ 296$ (1940); DeL. CODE, c. 175, § 22 (1935); GA. CODE § 114-305 (1937); IDAHO CODE, tit. 43, c. 12, §43-1202 (1932); KAN. Gen. StaT., c. 44, §520a (1947 Supp.); KY. REv. Stat. $\S 342.185$ (1948); ME. Rev. STaT., c. 26, §33 (1944); MonT. REv. CODES, c. 256, $\$ 2899$ (Anderson \& McFarland, 1935); N.H. Rev. Laws, c. 216, §16 (1941); N.J.S.A. § 34:15-51 (1937); N.Y. Work. CoMp. LaW $\$ 28$ (McKinney, 1948 Supp.); N.C. GEN. StaT., c. 97, $\S 97-24$ (1943); Ore. Laws $\$ 102-1771$ (e) (1940); Penna. StaT., tit. 77, $\$ 602$ (Purdon, 1947 Supp.); S.C. Crv. Code $\S 7035-27$ (1942); VA. CoDE, tit. 16, c. 76A, $\S 1887$ (25) (1942). But see notes 6 and 7 infra.

6. Nor do courts always find the distinction significant. Both North Dakota and Michigan have "injury" statutes. N. D. REv. CODE, c. 65, § 65-0501 (1943) (claim must be filed within year of injury); Mich. STAт., tit. 17, $\$ 17.165$ (1947 Supp.) (claim must be filed within six months of injury; claims for disability developing after this time but within two years after date of injury must be filed within three months after they become apparent). Yet their courts have equated "injury" with "accident," in effect placing these states in the group listed note 5 supra. Bjorseth v. North Dakota Workmen's Compensation Bureau, 62 N.D. 623, 244 N.W. 515 (1932); Hirsch v. Federal Steel Corp., 274 Mich. 406, 264 N.W. 844 (1936). Unfortunately, the reverse process cannot be so easily accomplished unless there is a statutory loophole like those cited note 7 infra.

7. This harsh result is avoided by three states which, though providing that the period of limitations runs from the date of accident, permit an extension upon a showing of "mistake of facts" or "other reasonable cause" for delay in filing a claim, MASs. LAW, c. 152, $\$ 41$, $\S 49$ (1942), Nev. Laws $\$ 2716$ (Hillyer, 1929), or "good cause" for the delay, Tex. Civ. STaT., tit. 130, art. 8307, $\$ 4$ a (V.A.C.S., 1948 Supp.). In effect, these provisions approximate the "injury" statutes despite their "accident" languages, and will be so treated in this Note. $C f$. Texas Employer's Ins. Ass'n v. Frankum, 145 Tex. 658, 201 S.W. $2 d 800$ (19.17).

8. 228 N.C. 447 , 46 S.E.2d 109 (1948). 
tiff had been struck in the eye by a metal chip, an accident regarded as trivial by both the company doctors and the plaintiff himself. No compensable injury appeared until eighteen months later, when a cataract resulted. Because no claim had been filed within the prescribed limitation of a year after the "accident," the Supreme Court of North Carolina felt constrained by the wording of the statute to deny compensation even though, in all other respects, claimant had established a prima facie case. ${ }^{3}$

While depriving the plaintiff of a bona fide claim merely because his injury did not manifest itself sooner seems contrary to the purpose of workmen's compensation, ${ }^{10}$ it is difficult to see how courts saddled with a strict "accident" statute can avoid this result." A possible judicial device would be to classify latent injuries as occupational diseases, since the period of limitations for the latter usually starts to run only upon the appearance of the disease. ${ }^{12}$ Such a decision would be strongly supported by analogy, for both are initially hidden and progressive in nature. ${ }^{13}$ But no complete answer is afforded by this rationale. One fourth of the states exclude occupational diseases from their compensation provisions, ${ }^{14}$ while others delimit

9. Id. at $448,419,46$ S.E.2d at 109,110 . Under a strict "accident" limitation, to bar recovery on this ground is customary. E.g., Central Locomotive \& Car Worls v. Industrial Comm., 290 IIl. 436, 125 N.E. 369 (1919) (blindness developing three years after the aceident); Fiorella v. Clark, $298 \mathrm{Ky} .817,184$ S.W.2d 208 (1944) (spine injury developing two years after the accident); Lewis v. Carnegie Ill. Steel Corp., 159 Pa. 226, 48 A.2d 120 (1946) (cataract developing five years after the accident).

10. See Mr. Justice Pitney in New York Central R. Co. v. White, 243 U.S. 189, 203, 204 (1917): ". . . there is more or less of a probability that the employee may loce his life through some accidental injury arising out of the employment, leaving his widow or clildren deprived of their natural support; or that he may sustain an injury not mortal but resulting in his total or partial disablement. . . . The physical suffering must be borne by the employee alone. . . . But, besides, there is a loss of carning power . . . an expense of the operation, as truly as the cost of repairing broken machinery. . . . It is not unreasonable for the state . . . to require [the employer] to contribute a reasonable amount . . . irre pretive of the question of negligence, instead of leaving the entire loss . . . upon the injured employee or his dependents."

11. See, e.g., Central Locomotive \& Car Works v. Industrial Comm., 290 1ll. 436, 439, 410,125 N.E. 369, 370 (1919): "The legislature has seen fit to fix the time for maling claims for compensation at six months after the accident. . . These provisions are within the domain of legislative power and the court is without authority to modify them. If they operate unjustly, the remedy is in the amendment of the law."

12. E.g., General Statutes of ConN., c. 280, $\$ 5245$ (Revision of 1930); Farmer v. Bieber-Goodman Corp., 118 Conn. 299, 172 Atl. 95 (1934) (mercurial poisoning). Sometimes the prescriptive period begins only with total disability and incapscity to worls. E.g., Cal. Labor CodE, Div. IV, c. 2, \$5405 (Deering, 1943); Mlarsh v. Industrial Accident Commission, 217 Cal. 338, 18 P.2d 933 (1933) (pneumoconiosis). See also Note, 86 A.L.R. 572 (1933).

13. While courts have rarely applied this reasoning, sec Creamery Plig. Mifg. Co. v. Industrial Comm., 226 Wis. $429,431,277$ N.W. 117, 119 (1938) (blindness eventuating from condition caused by injury is "alsin or in the nature of a slowly developing disease which ultimately caused blindness").

14. These include Alabama, Colorado, Florida, Louisiana, Mraine, Montana, New 
coverage to a few specified maladies. ${ }^{16}$ And even where the device is not thus precluded, courts might still be chary of permitting recovery as if an "injury" type statute were in effect.18

Since courts have found the "accident" type statutes too rigid for manipulation, legislatures must adopt other varieties of limitation if recovery for latent injuries is to be permitted. A few states, still leery of stale claims, have compromised by enacting a hybrid statute which provides a period of limitations running from the date of the accident but extending substantially longer for latent than for immediately apparent injuries. ${ }^{17}$ While the area of coverage is thus expanded, compensation is nevertheless denied where meritorious claims develop after the period has run..$^{18}$

The only statutes which insure recovery for all latent injuries are those hinging the period of limitation on manifestation of the injury itself, and this is the type adopted by most states. ${ }^{19}$ But the recent defection of five members of the majority ${ }^{20}$ raises the question of whether such a provision unduly exposes an employer to stale or fraudulent claims by permitting a period so long that witnesses may have either scattered or forgotten details of the accident. $^{21}$

If employers were required to prove the failure to comply with limitations as an affirmative defense, the qualms of these states might be justified. But once the defense is asserted, courts invariably place on the employee the burden of establishing the date of compensable injury. ${ }^{22}$ Moreover, most states hold that the employee must assert and prove, as a condition precedent to recovery, that limitation provisions do not bar his claim. ${ }^{23}$ In cither case he must show that, by exercising the care expected of a "reasonable man," he did not or could not have discovered the extent of his injuries prior to the date he alleges. ${ }^{24}$ Recovery is denied if the claimant's failure to file within

Hampshire, South Carolina, Tennessee, and Vermont. See 3 ScuneIder, WorkMen's Compensatron Text $\$ 924-1040$ (3rd ed. 1941).

15. E.g., Arizona, Arkansas, New Jersey, Pennsylvania, Rhode Island. For a complete synopsis of occupational disease statutes see SCHNEIDER, ibid.

16. See note 11 supra.

17. La. Gen. Stat., supra note 5; Mich. Stat. Ann., supra note 6; N. Y. Work. Cour. LAW, supra note 5.

18. E.g., Anderson v. Champagne, 8 So.2d 373 (La. App. 1942) (claim for tumor developing four years after the accident held barred by the prescriptive period).

19. See notes 2 and 7 supra.

20. See note 5 supra.

21. The difficulty of rebutting a trumped-up claim may thus be enhanced. See 1 Wood, LIMITATIONS § 4 (1916); HoRovirz, op. cit. supra, note 1, at 248.

22. California, for instance, specifically makes the statute of limitations an affirmative defense. Californa Code $\S 5409$ (Deering, 1947 Supp.). But once the employer raises the defense, the burden shifts to the employee to prove that he made timely claim. New Amsterdam Casualtỳ Co. v. Industrial Accident Comm. of the State of California, $66 \mathrm{Cal}$. App. 86, 225 P. 459 (1924). See Note, 78 A.L.R. 1299 (1932).

23. E.g., Menna v. Mathewson, 48 R.I. 310, 312, 137 Atl. 907, 908 (1927). See Note, 78 A.L.R. 1294 (1932).

24. E.g., Wis. Stat., c. 102, $§ 102.12$ (1947). Other jurisdictions have adopted this test 
the statutory period was caused by his own negligence or ignorance of his rights. ${ }^{25}$ These requirements seem to protect the employer sufficiently against stale or fraudulent claims.

The injury type statute, therefore, is sufficiently flexible to permit courts to sort justifiable claims based on latent injuries from those delayed because the employee "slept on his rights." Admittedly, the danger of fraud grows as the period of limitation lengthens. ${ }^{\circ}$ But where a causal relationship between accident, injury, and disability exists, recovery should not be precluded merely because of delay for which the employee cannot be blamed. States which have adopted the "accident" type statute would do well to reconsider the question of whether it fulfills the basic principle of compensation for which it was designed.

judicially. E.g., Hickman v. Dunlop Tire \& Rubber Co., 238 MIo. App. 573, 185 S.IV.2d 874 (1945); Clausen v. Minnesota Steel Co., 186 Minn. S0, 242 N.W. 397 (1932); Anderzen v. Contract Trucking Co., 4 S N.M1. 158, 146 P.2d 873 (1941).

25. The generally accepted rule is that ". . . indifference or neglect or failure to ascertain one's legal rights does not constitute 'good cause' for failure to fle a claim." Auburn v. Liability Assurance Corp., 77 F.2d 749, 750 (5th Cir. 1935) (applying Tevas statute). Although an unconscious presumption in favor of the employee may operate on ocession, courts finding that an allegedly latent injury was apparent at the time of the accident have not hesitated to bar the claim if filed after the limitation period beginning at that date has expired. Sun Oil v. Barkley, 14S Okla. 208, 298 P. 280 (1931); Bruggeman v. Ford Motor Co., 225 Minn. 427, 30 N.W.2d 711 (1948).

26. See note 21 supra. 